inOedia $\quad \begin{aligned} & \text { InMedia } \\ & \text { The French Journal of Media Studies }\end{aligned}$

3 | 2013

Cinema and Marketing

\title{
Richard Osborne, Vinyl: A History of the Analogue Record
}

Farnham: Ashgate, 2012, 213 pages

\section{Claude Chastagner}

\section{(2) OpenEdition \\ Journals}

Electronic version

URL: http://journals.openedition.org/inmedia/548

DOI: $10.4000 /$ inmedia. 548

ISSN: 2259-4728

Publisher

Center for Research on the English-Speaking World (CREW)

Electronic reference

Claude Chastagner, «Richard Osborne, Vinyl: A History of the Analogue Record », InMedia [Online], 3|

2013, Online since 15 April 2013, connection on 24 September 2020. URL : http://

journals.openedition.org/inmedia/548; DOI : https://doi.org/10.4000/inmedia.548

This text was automatically generated on 24 September 2020.

(C) InMedia 


\section{Richard Osborne, Vinyl: A History of the Analogue Record}

Farnham: Ashgate, 2012, 213 pages

Claude Chastagner

\section{REFERENCES}

Richard Osborne, Vinyl: A History of the Analogue Record, Farnham: Ashgate, 2012, 213

$\overline{\text { pages }}$ 
1 January 2013 was marked in France by the news that all the country's Virgin stores, the main purveyor of CDs with Fnac, were about to close down. At the same time, in my hometown of Montpellier, a limited, but steady number of record stores remain open. Small, independent, they all stock mostly, or only, vinyls, the black, 33 rpm, analogue records of the past. The situation is similar in Britain, and in the USA. In London, Brighton, Colorado Springs, Austin, New York, one finds thriving second hand record stores. They may sell the occasional $C D$, but their mainstay is vinyl. Since 2007, Record Store Day, an international event aiming at fostering the survival of independent record stores, has been gaining momentum in western countries. Rock musicians contribute by recording special

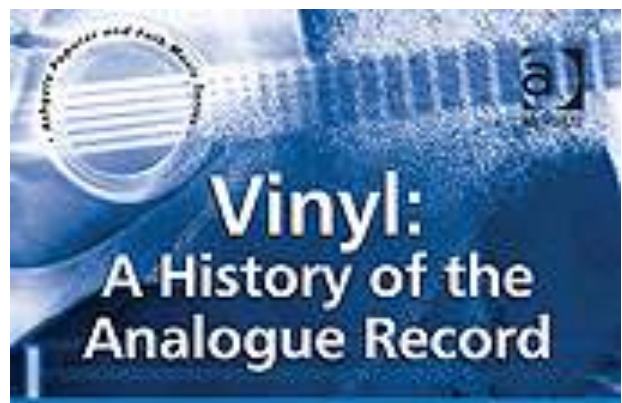
music, limited editions made available on vinyl only. Increasingly, record companies, like Montreal's Constellation, release their artists' music systematically on CDs and vinyls; they sometimes include a free 7" (vinyl) record with the mail orders they ship. A growing number of artists make their music available only as digital downloads and in vinyl. Market analysts and fans alike claim that vinyl is back, or that it has never left. But whatever the perspective, something is definitely going on. Something all the more fascinating as, though music purchases on the whole are dwindling, partly because of illegal downloading according to the music industry, analogue records' sales increased by a significant $43.7 \%$ in Britain in 2011, and by similar figures in the USA.

2 To document and explain these current trends, Richard Osborne has just released the most perfect book: a history of vinyl that does not neglect aesthetic or interpretative considerations, but focuses also on hard facts, and pays attention to technology, and economics. The fate of vinyl analogue records may seem trivial compared with more momentous issues such as the current turmoil the written press is experiencing, or the implosion of traditional television viewing patterns, but the (his)story of vinyl extends beyond the world of collectors, or music specialists, into the larger field of contemporary media studies. It highlights its current contradictions and uncertainties, beyond the sheen of the all-digital revolution, and points at the interconnection between communication, media, and the arts. It is also extremely revealing of the fragmentation and intricacies of contemporary consumer society, of the complex motives that justify trends and consumer choices. On all these accounts, despite its technical, and thus modest appeal, Osborne's book proves a fascinating and essential read, and an elegant one at that.

Osborne concludes that if to a certain extent, digital technologies are not formats at all, in contrast, analogue recording focuses on the issue of format, and its numerous implied parameters (size, shape, tone, duration, categorization in genres, etc.). Vinyl is 
also related to more sociological or artistic elements, such as the interplay between format and content, and it has been an essential factor for the creation and perception of recorded music (183). He also insists on the specificity of vinyl, things other formats (or non-formats) such as cassettes, CDs, or digital downloads cannot do: being an effective branding tool which is clearly associated, by means of the inner label and the sleeve, to a specific record company; an exclusive recording device (it is practically and financially impossible to make a home-made vinyl record, one needs to have been selected by a record company, however small); and a desirable, collectable object, coming in different shapes, colors, sizes, weights, with a distinctive touch and smell.

Osborne's demonstration serves several purposes: to tell the history of the vinyl record, to explore its relationship with music, and to address the reasons for its appeal. The specificity and originality of Osborne's approach is his focus on the anatomical: the distinct auditory, visual, and tactile qualities of the object, which leads him to tackle vinyl from technological, commercial, or economic perspectives. Another strength of his essay is the careful distinction he establishes, within each chapter and subdivision, between the British and the American scenes. It also summons the key players: the artists, the industry people (major and independent record company executives, the written and electronic press, and Madison avenue), and the audience, by means of reception studies.

5 The organization of the book follows the same historical, geographical, and anatomical foci, with an abundance of precise data, first-hand accounts, and numerous, rare primary sources. Chapter one examines the groove (not in the musical sense of a given rhythm, but the one inscribed on the surface of the record), and the impact of being able to see and touch the fragile, perishable, mortal coil of music. Chapter two tells the history of the format per se, the progressive ascendancy of disc over cylinder. Chapter three addresses the label, the piece of paper glued onto the surface of the disc, giving details about the music, and enabling the practice of labeling, with the ensuing impact on genre and categorization. The fourth chapter is concerned with vinyl (as a chemical product different from wax or shellac), and the changing perceptions attached to this cheap plastic product. The fifth chapter looks at the emergence of the LP as the dominant format, from classical music to pop and rock, and the consequences of such a meteoric rise, while chapter six details the complementary 7" (45 rpm) format and chapter seven focuses on the specificities of b-sides and 12" singles. The last chapter traces the history and implications of the sleeve. These 8 chapters focus mostly, at least for the post-1945 period, on pop or rock music (with an easily understandable emphasis on the innovations brought about by The Beatles), with a few insights into jazz, classical, and "popular" music recordings, mostly by means of comparison. The book concludes with a lengthy bibliography and an index.

Osborne combines rare but meaningful details, such as those on very recent technological developments, with comprehensive and perfectly synthesized historical surveys, while raising stimulating points and bringing into question many assumptions and received ideas. He is also careful to never let any fetishism come in the way of analysis and readily admits that the attention vinyl receives is out of all proportion to its market performance: his core argument is that the vinyl record has been 'articulated' (3), and that its different components (label, material, sleeve, size, etc.) have been used to advance specific musical causes and values, a claim I would extend beyond music. Osborne's refreshing attention to the materiality of his object could 
indeed be applied with similar success to other objects from the field of media and communication. It is quite telling that his book was released at the same time as a history of EMI Records or a study of the art of British rock.

7 The reader, stimulated and provoked by Osborne's study, can only wish that he had extended the same kind of analysis and degree of perfection to the various technical means used to play vinyls records, from cheap monophonic record players to state-ofthe-art hi-fi sets.

\section{AUTHORS}

\section{CLAUDE CHASTAGNER}

Université Paul Valéry, Montpellier 3 